\title{
Use of Tissue Doppler Imaging in horses - exercise stress echocardiography with Tissue Doppler Imaging in healthy horses and horses with cardiac disease
}

\author{
Charlotte Hopster-Iversen', Heidrun Gehlen² and Peter Stadler \\ ${ }^{1}$ Klinik für Pferde, Stiftung Tierärztliche Hochschule Hannover \\ 2 Klinik für Pferde, Allgemeine Chirurgie und Radiologie, Freie Universität Berlin
}

\begin{abstract}
Summary: The evaluation of performance capacity with exercise test is of particular importance in horses with mild to moderate valvular regurgitations as a possible exercise intolerance, and a detrimental cardiac function is often first detected after exercise. Aim of the study was the comparison of myocardial velocities evaluated with Tissue Doppler imaging in healthy horses and horses with a cardiologic disease. 20 adult warmblood horses without cardiovascular diseases and 40 horses with valvular regurgitation or atrial fibrillation were examined. The examination included a clinical examination and standard electro- and echocardiographic examinations at rest. Additionally, the left ventricular septum (IVS) and the left ventricular free wall (LVW) were evaluated with tissue Doppler imaging at rest and after lung exercise. The peak systolic (S), early diastolic (E-Wave) and late diastolic (A-Wave) myocardial velocities were analysed with colour-coded Tissue Doppler and imaging (TVI) and with PW-Tissue Doppler Imaging respectively. Horses with atrial fibrillation $(n=15)$ showed an increase of systolic myocardial velocities at rest (TVI: IVS: control: $-3.92 \pm 1.54 \mathrm{~cm} / \mathrm{s}, \mathrm{AF}:-6.66 \pm 3.26 \mathrm{~cm} / \mathrm{s}, \mathrm{p}<0.0001$, LVW: control: $7.14 \pm 1.18 \mathrm{~cm} / \mathrm{s}$, AF: $10.03 \pm 3.10 \mathrm{~cm} / \mathrm{s}, \mathrm{p}<0.0001$ ) and after exercise (PW: IVS: control: $-13.37 \pm 3.84 \mathrm{~cm} / \mathrm{s}, \mathrm{AF}:-17.15 \pm 3.93 \mathrm{~cm} / \mathrm{s}$, $p<0.005$, LVW: control: $13.53 \pm 3.66 \mathrm{~cm} / \mathrm{s}, \mathrm{AF}: 17.95 \pm 3.50 \mathrm{~cm} / \mathrm{s}, \mathrm{p}<0.001)$ compared to the healthy control horses. Furthermore, the group of horses with atrial fibrillation had higher early diastolic myocardial velocities then the control horses (TVI: IVS: control: $12.34 \pm 2.91 \mathrm{~cm} / \mathrm{s}$, AF: $16.70 \pm 6.13 \mathrm{~cm} / \mathrm{s}, \mathrm{p}<0.001$, LVW: control: $-17.32 \pm 5.25 \mathrm{~cm} / \mathrm{s}, \mathrm{AF}:-22.25 \pm 5.19 \mathrm{~cm} / \mathrm{s}, \mathrm{p}<0.01)$. Horses with mitral valve regurgitation $(n=15)$ also had higher systolic myocardial velocities, but only at rest compared to the healthy control horses (PW: IVS: control: $-8.36 \pm 1.78 \mathrm{~cm} / \mathrm{s}, \mathrm{MVI}:-10.99 \pm 3.13 \mathrm{~cm} / \mathrm{s}, \mathrm{p}<0.005)$, while horses with aortic valve regurgitations ( $\mathrm{n}=10)$ had higher early diastolic myocardial velocities at rest (PW: IVS: control: $17.06 \pm 3.85 \mathrm{~cm} / \mathrm{s}, \mathrm{AVI}: 20.30 \pm 3.59 \mathrm{~cm} / \mathrm{s}, \mathrm{p}<0.05)$, but higher late diastolic velocities after exercise compared to the healthy control horses (TVI: LVW: control: $-8.62 \pm 3,7 \mathrm{~cm} / \mathrm{s}, \mathrm{AVI}:-11.86 \pm 2.05 \mathrm{~cm} / \mathrm{s}$, $p<0.05)$. The myocardial analysis with Tissue Doppler imaging was feasible at rest and after exercise. The increase of myocardial velocities in the horses with cardiovascular disease is probably the result of an increase in contractility due to increased filling pressure of the ventricle in the presence of adequate ventricular capacity.
\end{abstract}

Keywords: echocardiography / Tissue Doppler Imaging / exercise / cardiology

Einsatz der Gewebedoppleruntersuchung beim Pferd - Vergleich stressechokardiographischer Gewebedopplermessung bei gesunden und herzkranken Warmblutpferden

In der Funktionsdiagnostik des Myokards kann die Methode der Gewebedopplerechokardiographie zur objektiven Beurteilung herangezogen werden. Ziel dieser Studie war der gewebedopplerechokardiographische Vergleich zwischen 20 herzgesunden und 40 herzkranken Pferden in Ruhe und nach Longenbelastung. Bei allen Pferden wurde eine klinische Untersuchung in Ruhe und elektro- und echokardiographische Untersuchungen (B- und M-Mode, Farb- und Gewebedoppler) vor und nach standardisierter Belastung an der Longe durchgeführt. Nach Belastung erfolgte die Darstellung des Herzens in der rechten kaudalen kurzen Herzachse (RKDKA) mit Analyse der Myokardbewegung, der systolischen Spitzengeschwindigkeit, der frühdiastolischen Relaxation (E-Welle) und der spätdiastolischen Relaxation (A-Welle) im Bereich des interventrikulären Septums (IVS) und der linksventrikulären Hinterwand (LVW) mit Farbgewebedoppler (TVI) als auch mit PW-Gewebedoppler (PW). Nach der echokardiographischen Voruntersuchung wurden die herzkranken Pferde in 3 Gruppen eingeteilt: Mitralklappeninsuffizienz (15 Pferde), Aortenklappeninsuffizienz (10 Pferde), und Vorhofflimmern (15 Pferde). Die Pferde mit Vorhofflimmern $(n=15)$ zeigten sowohl in Ruhe (TVI: IVS: gesund: $-3,92 \pm 1,54 \mathrm{~cm} / \mathrm{s}, \mathrm{VF}:-6,66 \pm 3,26 \mathrm{~cm} / \mathrm{s}, \mathrm{p}<0,0001, \mathrm{LVW}:$ gesund: $7,14 \pm 1,18 \mathrm{~cm} / \mathrm{s}$, VF: 10,03 $\pm 3,10 \mathrm{~cm} / \mathrm{s}, \mathrm{p}<0,0001$ ) wie auch in Belastung (PW: IVS: gesund: $-13,37 \pm 3,84 \mathrm{~cm} / \mathrm{s}, \mathrm{VF}:-17,15 \pm 3,93 \mathrm{~cm} / \mathrm{s}, \mathrm{p}<0,005$, LVW: gesund: 13,53 $\pm 3,66 \mathrm{~cm} / \mathrm{s}$, VF: $17,95 \pm 3,50 \mathrm{~cm} / \mathrm{s}, \mathrm{p}<0,001)$ höhere systolische Myokardgeschwindigkeit als die herzgesunden Probanden. Weiterhin kam es in Ruhe zu einer Erhöhung der frühdiastolischen Myokardgeschwindigkeiten (TVI: IVS: gesund: $12,34 \pm 2,91 \mathrm{~cm} / \mathrm{s}, V F: 16,70 \pm 6,13 \mathrm{~cm} / \mathrm{s}, \mathrm{p}<0,001$, LVW: gesund: $-17,32 \pm 5,25 \mathrm{~cm} / \mathrm{s}, \mathrm{VF}:-22,25 \pm 5,19 \mathrm{~cm} / \mathrm{s}, \mathrm{p}<0,01)$ im Vergleich zu den herzgesunden Probanden. Die Pferde mit Mitralklappeninsuffizienz zeigten eine Erhöhung der systolischen Myokardgeschwindigkeiten, allerdings nur in Ruhe (PW: IVS: gesund: $-8,36 \pm 1,78 \mathrm{~cm} / \mathrm{s}, \mathrm{MVI}:-10,99 \pm 3,13 \mathrm{~cm} / \mathrm{s}, \mathrm{p}<0,005)$. Dagegen wurde die Myokardgeschwindigkeit bei den Pferden mit Aortenklappeninsuffizienz frühdiastolisch in Ruhe (PW: IVS: gesund: 17,06 $\pm 3,85 \mathrm{~cm} / \mathrm{s}, \mathrm{AVI}$ : $20,30 \pm 3,59 \mathrm{~cm} / \mathrm{s}, \mathrm{p}<0,05)$ und spätdiastolisch nach Belastung im Vergleich zu den herzgesunden Probanden erhöht (TVI: LVW: gesund: $-8,62 \pm 3,7 \mathrm{~cm} / \mathrm{s}, \mathrm{AVI}:-11,86 \pm 2,05 \mathrm{~cm} / \mathrm{s}, \mathrm{p}<0,05)$. Im Rahmen dieser Studie war die Methode der Gewebedopplerechokardiographie sowohl in Ruhe wie auch nach Belastung anwendbar. Weiterhin zeigte sich eine Zunahme der Myokardgeschwindigkeiten bei den herzkranken Probanden, wahrscheinlich als Ausdruck einer erhöhten Ventrikelarbeit bei noch ausreichendem Kontraktilitätsvermögen.

Schlüsselwörter: Echokardiographie / Gewebedoppler / Belastungsuntersuchung / Kardiologie

Correspondence: Dr. Charlotte Hopster-lversen, Stiftung Tierärztliche Hochschule Hannover, Klinik für Pferde, Bünteweg 9, 30559 Hannover, E-Mail: charlotte.iversen@gmx.de

Citation: Hopster-Iversen C., Gehlen H., Stadler P. (2014) Use of Tissue Doppler Imaging in horses - exercise stress echocardiography with Tissue Doppler Imaging in healthy horses and horses with cardiac disease. Pferdeheilkunde 30, 444-454 


\section{Introduction}

Cardiovascular diseases are the second most common reason for poor performance after obstruction of the airways and before muscular-skeletal diseases (Martin et al. 2000). While the occurrence of heart murmurs in thoroughbreds is not necessarily associated with the performance capacity (Kriz et al. 2000, Young et al. 2008), the importance of heart murmurs in warmblood horses without further examinations is often unclear. Echocardiographic examinations, exercise-ecg and additionally $24 \mathrm{~h}$-ecg recordings are recommended for further evaluation of the cardiac function (Gehlen 2010). The evaluation of performance capacity with exercise test is of particular importance in horses with mild to moderate valvular regurgitations as a possible exercise intolerance, as well as a detrimental cardiac function is often first detected after exercise. The standard echocardiographic examination includes the measurement of the heart dimensions as well as colour Dopplersonographic examination of the heart valves (Patteson et al. 1995). Additionally, evaluation of the myocardial function is of importance. A method of objective analysis of myocardial function is Tissue Doppler Imaging (TDI) also known as Tissue Velocity Imaging (TVI) (Pellerin et al. 2003). The analysis of myocardial velocities can be realized with colour-Doppler as well as with PWDoppler (Voigt 2002). In human medicine, Tissue Doppler imaging is used for the diagnosis of ischaemic heart diseases and evaluation of diastolic dysfunction (Bruch et al. 1999, Edvardsen et al. 2002), in the early detection of dilative cardiomyopathy (Fukuda et al. 1998, Mishiro et a. 1999), and to distinguish between hypertrophic cardiomyopathy and exercise-induced hypertrophy (Cardim et al. 2003). In humans with valvular insufficiencies, changes of early diastolic velocities (E-Wave) have been detected dependent of severity of valvular insufficiency and diastolic dysfunction (Abe et al. 1999, Agricola et al. 2004). Stress echocardiographic examinations have detected a correlation between exercise intolerance and decreased systolic and late diastolic myocardial velocities in the left ventricle in humans (Witte et al. 2004). In human infarct patients, decreased systolic myocardial velocities were detected in comparison to healthy control subjects (Dagianti et al. 2000).

When performing stress echocardiographic myocardial analysis, the method of colour-coded Doppler Imaging is rather recommended, because of the possibility to perform off-line analysis of different myocardial segments after recording of cardiac cycles (cine-loops) (Nikitin and Witte 2004). However, colour coded Tissue Doppler Imaging derived myocardial velocities are only average velocities, while PW-Tissue Doppler Imaging detects the upper limits of myocardial velocities (McCulloch et al. 2006).

The radial, circumferential, and longitudinal myocardial velocities can be analysed with Tissue Doppler Imaging. However, while in human medicine an apical ultrasonographic window is usually used with recording of longitudinal myocardial velocities, in horses, the parasternal ultrasonographic window only allows the detection of radial myocardial velocities with the standard Tissue Doppler Imaging (Flachskampf 2002, Sepulveda et al. 2005). Previous studies in horses with Tissue Doppler Imaging include testing of practicability (Sepulveda et al. 2005, Schwarzwald et al. 2009, Michutta 2012), effects of lung disease (Gehlen und Neukirch 2013), atrial fibrillation at rest (Schwarzwald et al. 2007, Decloedt et al. 2013) and after exercise (Gehlen et al. 2009, Schefer et al. 2010), as well as evaluation of cardio toxicity (Decloedt et al. 2012, Verheyen et al. 2012) and effects of sedation (Nagel und Gehlen 2012).

Aim of the study was the comparison of myocardial velocities at rest and after exercise in healthy horses and horses with cardiac diseases (valve insufficiencies or atrial fibrillation). Furthermore, it should be evaluated if valvular insufficiencies had an effect on myocardial velocities as was the case in humans. If such an effect would be detected, a further detection of myocardial dysfunction but also a more in-depth assessment of performance capacity and the development of cardiac disease as in humans (Jassal et al. 2009) and dogs (Chetboul et al. 2004) would maybe also be possible in horses.

\section{Material and methods}

\section{Study population}

The study population was composed of 60 warmblood horses, which were in part patients of the equine clinic of the University of Veterinary Medicine Hannover and on the other side clinic-owned horses. Of the examined horses were 20 without cardiac diseases and 40 with valvular diseases or atrial fibrillation.

\section{Examination}

The anamnesis was recorded and a clinical and specific cardiological examination performed on all horses. Furthermore, an echocardiographic standard examination at rest and electrocardiographic examination at rest and in exercise were carried out. The standard echocardiographic examination was undertaken with the ultrasound machine Vivid 7 (GE) and the heart imagined in the standard echocardiographic planes according to Stadler et al. (1998) and the dimensions of the heart measured. A dopplersonographic examination was used to detect any valvular regurgitation, which was graduated according to the vena contracta size adapted from Gehlen (1997).

The Tissue Doppler Imaging examination was performed at rest and after exercise. The regions of interest were the interventricular septum (IVS) and the left-ventricular free wall (LVW), which were imagined, in the short-axis view directly below the chordae tendinae. The depth of the ultrasound image was set to $28 \mathrm{~cm}$ with an angle of $70^{\circ}$ to achieve an image rate above $60 \mathrm{fps}$. The systolic peak velocity, the early diastolic filling (E-Wave) and the late or atrial diastolic filling (A-Wave) of the myocardium were recorded with PW-Tissue Doppler and colour-coded Tissue Doppler. The mean velocity of the peak velocity of the systolic, $E_{-}$, and A-wave was calculated from 3 heart cycles.

The exercise test was composed of 5 minutes of walking, 10 minutes of trot, and 5 minutes of canter. The stress echocardiographic examination was carried out immediately after end of exercise. If the heart rate was below 100 beats/minute, the horse was exercised for another few minutes in canter. 


\section{Statistical analysis}

The mean and standard deviations were calculated in all horses with the statistic program SAS ${ }^{\circledR}$ from three heart cycles without arrhythmia. In horses with atrial fibrillations, mean and standard deviation were calculated from five heart cycles. The values were tested for normal distribution and normal distributed values analysed with a paired t-test, while not normal distributed values were analysed with the Wilcoxon-Test. The level of significance was set at $p<0.05$. Comparisons were made between control subjects and subjects with valvular regurgitation respectively atrial fibrillation at rest and after exercise.

\section{Results}

\section{Pre-examinations}

\section{Control subjects}

The mean age of the 20 control horses $(5$ mares, 15 geldings) was $11 \pm 5$ Years (3-20 Years), the mean weight $605 \pm 72 \mathrm{~kg}(435-705 \mathrm{~kg})$, and the mean height $168 \pm 5 \mathrm{~cm}$ $(158-180 \mathrm{~cm})$. In all control subjects, the clinical examination was without any abnormal findings. In the echocardiographic pre-examination, the dimensions of the heart were all within the normal limits of warmblood horses. In two horses, physiological regurgitations were found at the aortic valves, while another horse showed physiological regurgitations at the tricuspidal-and at the pulmonary valve.

Horses with cardiac diseases

After the pre-examinations, 40 warmblood horses were included in the study. Horses were excluded if there were clinical signs of a lung disease, or if the body condition did not allow sufficient imaging of the heart. This resulted in a study population of 40 horses. Of the 40 horses, 15 horses had a mitral valve insufficiency, 10 horses an aortic valve insufficiency, and 15 horses atrial fibrillation. The group distribution was performed after the echocardiographic and electrocardiographic examination. Horses with mitral- or aortic valve insufficiency were only included if they only had pathological regurgitations at one heart valve (mitral or aortic valve).
Horses with mitral valve insufficiency (MVI, $n=15)$

The mean age of the horses with mitral valve insufficiency was $9 \pm 5$ years $(4-21$ Years), the mean weight $572 \pm 44 \mathrm{~kg}$ $(515-660 \mathrm{~kg})$, and the mean height $168 \pm 5 \mathrm{~cm}$ $(155-173 \mathrm{~cm})$. After evaluation of the severity of the mitral valve insufficiency after measurements of the Vena contracta, 12 horses had a mild MVI, 2 horses a moderate MVI, and one horse a severe MVI.

Horses with aortic valve insufficiency (AVI, $n=10)$

The mean age of the horses with aortic valve insufficiency was $13 \pm 4$ years $(5-18$ years), the mean weight $516 \pm 54 \mathrm{~kg}$ $(442-600 \mathrm{~kg})$, and the mean height $161 \pm 5 \mathrm{~cm}$ $(150-169 \mathrm{~cm})$. After evaluation of the severity of the mitral valve insufficiency after measurements of the Vena contracta, 5 horses had a mild AVI, 3 horses a moderate $A V I$, and 2 horses a severe AVI.

Horses with atrial fibrillation $(A F, n=15)$

The mean age of the horses with atrial fibrillation was $10 \pm 5$ years $(3-18$ years), the mean weight $597 \pm 74 \mathrm{~kg}$ $(480-705 \mathrm{~kg})$, and the mean height $173 \pm 9 \mathrm{~cm}$ $(160-186 \mathrm{~cm})$.

\section{Tissue Doppler examinations at rest}

The A-wave could not be analysed in the horses with atrial fibrillation because of the missing atrial contraction.

Examination with colour-coded Tissue Doppler at rest

The myocardial analysis with colour-coded Tissue Doppler Imaging at rest showed a significant increase of systolic and early diastolic myocardial velocities in the horses with atrial fibrillation (AF) compared to the control subject (Table 1). The increase was significant in the interventricular septum (Systole; control: $-3.92 \pm 1.54 \mathrm{~cm} / \mathrm{s}, \mathrm{AF}:-6.66 \pm 3.26 \mathrm{~cm} / \mathrm{s}$ $p<0.0001$, E-wave; control: $12.34 \pm 2.91 \mathrm{~cm} / \mathrm{s}$, AF: $16.70 \pm 6.13 \mathrm{~cm} / \mathrm{s}, \mathrm{p}<0.001$ ) as well in the left ventricular free wall (Systole; control: $7.14 \pm 1.18 \mathrm{~cm} / \mathrm{s}$, AF: $10.03 \pm 3.10 \mathrm{~cm} / \mathrm{s}, \mathrm{p}<0.0001, \mathrm{E}$-wave; control: $-17.32 \pm 5.25 \mathrm{~cm} / \mathrm{s}$, VF: $-22.25 \pm 5.19 \mathrm{~cm} / \mathrm{s}, \mathrm{p}<0.01)$.

\begin{tabular}{|c|c|c|c|c|}
\hline \multicolumn{5}{|c|}{$\begin{array}{l}\text { with mitral valve insufficiency (MVI), aortic valve insufficiency (AVI), or atrial fibrillation (AF). Values significant different from the values in the control } \\
\text { subjects are marked with *. IVS = interventricular septum, LVW = left ventricular free wall. } \\
\text { Ergebnisse für die mit dem Farbgewebedoppler ermittelten Myokardgeschwindigkeiten in Ruhe im Vergleich zwischen herzgesunden Probanden und } \\
\text { Pferden mit Mitralklappeninsuffizienz (MVI), Aortenklappeninsuffizienz (AVI) oder Vorhofflimmern (VF). Werte die signifikant unterschiedlich zu den } \\
\text { ermittelten Werten bei den gesunden Probanden waren sind mit * gekennzeichnet. IVS = Interventrikularseptum, LVW = Linksventrikuläre } \\
\text { Hinterwand. }\end{array}$} \\
\hline Parameter & Control $(n=20)$ & $\mathrm{MVI}(\mathrm{n}=15)$ & $\mathrm{AVI}(\mathrm{n}=10)$ & $\operatorname{VF}(n=15)$ \\
\hline IVS_Systole $(\mathrm{cm} / \mathrm{s})$ & $-3.92 \pm 1.54$ & $-4.56 \pm 2.25$ & $-4.5 \pm 2.06$ & $-6.66 \pm 3.26^{*} p<0.0001$ \\
\hline IVS_E-wave $(\mathrm{cm} / \mathrm{s})$ & $12.34 \pm 2.91$ & $13.08 \pm 3.92$ & $12.76 \pm 1.97$ & $16.70 \pm 6.13^{*} p<0.001$ \\
\hline IVS_A-wave $(\mathrm{cm} / \mathrm{s})$ & $2.86 \pm 1,92$ & $3.1 \pm 2.9$ & $2.73 \pm 1.6$ & / \\
\hline LVW_Systole $(\mathrm{cm} / \mathrm{s})$ & $7.14 \pm 1.18$ & $7.7 \pm 1.17$ & $7.75 \pm 1.33$ & $10.03 \pm 3.10^{*} p<0.0001$ \\
\hline LVW_E-wave $(\mathrm{cm} / \mathrm{s})$ & $-17.32 \pm 5.25$ & $-19.19 \pm 5.4$ & $-18.23 \pm 4.43$ & $-22.25 \pm 5.19^{*} p<0.01$ \\
\hline LVW_A-wave $(\mathrm{cm} / \mathrm{s})$ & $-7.42 \pm 1.96$ & $-7.27 \pm 3.57$ & $-7.28 \pm 2.66$ & / \\
\hline
\end{tabular}


Examination with PW-Tissue Doppler Imaging at rest

The myocardial analysis with PW-Tissue Doppler Imaging at rest identified a significant increase of systolic and early diastolic myocardial velocities in horses with atrial fibrillation in the interventricular septum (Systole; control: $-8.36 \pm 1.78 \mathrm{~cm} / \mathrm{s}$, AF: $-12.16 \pm 3.56 \mathrm{~cm} / \mathrm{s}, \mathrm{p}<0.0001$, E-wave; control: $\quad 17.06 \pm 3.85 \mathrm{~cm} / \mathrm{s}$, AF: $22.44 \pm 8.08 \mathrm{~cm} / \mathrm{s}, \mathrm{p}<0.005)$ as well in the left ventricular free wall (Systole; control: $11.15 \pm 3.05 \mathrm{~cm} / \mathrm{s}, \mathrm{AF}$ : $15.48 \pm 4.78 \mathrm{~cm} / \mathrm{s}, \quad \mathrm{p}<0.0005$, E-wave; control: $25.97 \pm 6.21 \mathrm{~cm} / \mathrm{s}, \quad A F:-31.81 \pm 7.84 \mathrm{~cm} / \mathrm{s}, \quad p<0.01)$ (Table 2). Horses with mitral valve insufficiency demonstrated an increase of systolic myocardial velocity in the interventricular septum compared to the control subjects (control: $\quad-8.36 \pm 1.78 \mathrm{~cm} / \mathrm{s}, \quad \mathrm{MVI}:-10.99 \pm 3.13 \mathrm{~cm} / \mathrm{s}$, $\mathrm{p}<0.005)$. Additionally, horses with aortic valve insufficiency (AVI) showed an increase of early diastolic myocardial velocity in the interventricular septum compared to the con- trol subjects at rest (control: $17.06 \pm 3.85 \mathrm{~cm} / \mathrm{s}, \mathrm{AVI}$ : $20.30 \pm 3.59 \mathrm{~cm} / \mathrm{s}, \mathrm{p}<0.05$ ) (Table 2).

\section{Exercise examination}

The control subjects as well as the horses with mitral- or aortic valve insufficiency were able to perform the complete exercise test, while the exercise had to be discontinued in four horses with atrial fibrillation due to inability to continue. The mean heart rates after exercise, as well as the mean velocity in trot and canter, are shown in table 3.

\section{Tissue Doppler Imaging after exercise}

A part of the examined horses demonstrated a fusion of the a-wave with the e-wave after exercise, so that the a-wave could not be measured. The number of horses were it was

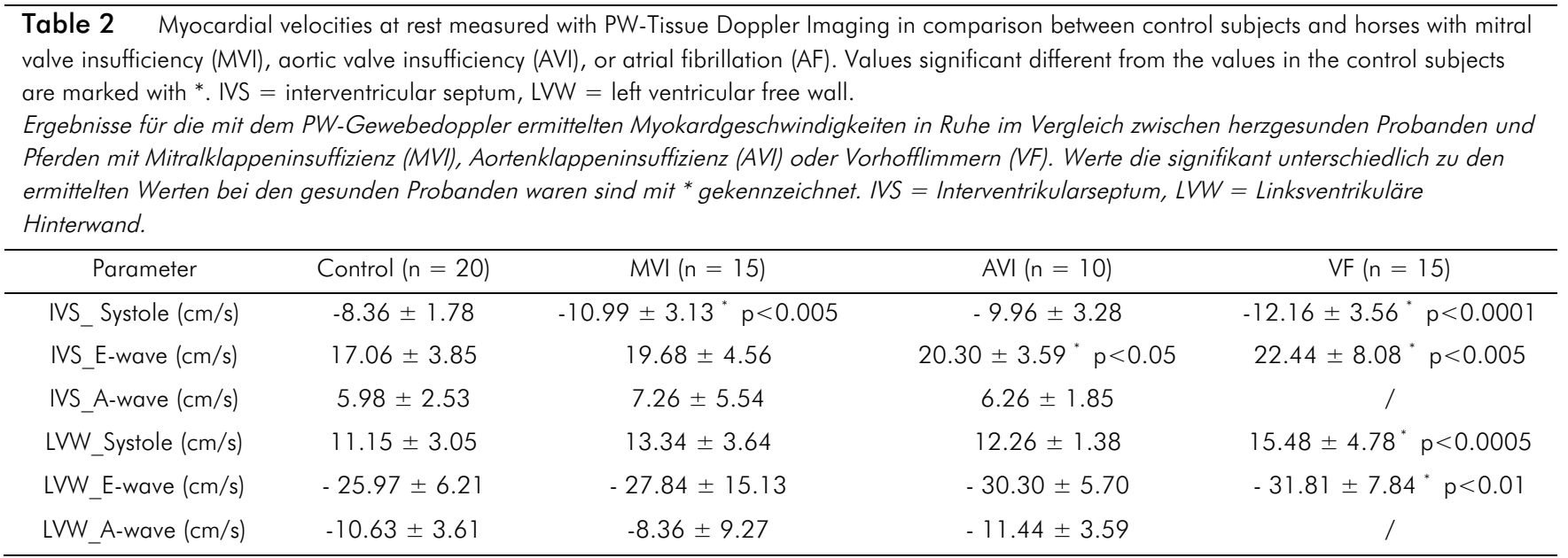

Table 3 Exercise test: mean velocity in trot and canter as well as heart rate after exercise in control horses, horses with mitral valve insufficiency (MV), aortic valve insufficiency (AVI), and atrial fibrillation (AF). BPM = beats per minute

Belastungsuntersuchung: Trab- und Galoppgeschwindigkeiten gesunder Probanden, sowie bei Pferden mit Mitralklappeninsuffizienz (MVI), Aortenklappeninsuffizienz (AVI) und Vorhofflimmern (VF). Bpm = Schläge/Minute

\begin{tabular}{|c|c|c|c|c|}
\hline & Control & MVI & $\mathrm{AVI}$ & VF \\
\hline Velocity in trot & $3.6 \mathrm{~m} / \mathrm{s}$ & $3.70 \mathrm{~m} / \mathrm{s}$ & $3.63 \mathrm{~m} / \mathrm{s}$ & $3.67 \mathrm{~m} / \mathrm{s}$ \\
\hline Velocity in canter & $5.6 \mathrm{~m} / \mathrm{s}$ & $5.25 \mathrm{~m} / \mathrm{s}$ & $5.94 \mathrm{~m} / \mathrm{s}$ & $4.52 \mathrm{~m} / \mathrm{s}$ \\
\hline Heart rate immediately after exercise & $129.7 \pm 23.23 \mathrm{bpm}$ & $113.17 \pm 25.27 \mathrm{bpm}$ & $130.1 \pm 23.65 \mathrm{bpm}$ & $128.13 \pm 30.74$ bpm \\
\hline
\end{tabular}

Table 4 Myocardial velocities after exercise measured with colour-coded Tissue Doppler Imaging in comparison between the control subjects and horses with mitral valve insufficiency (MVI), aortic valve insufficiency (AV), or atrial fibrillation (AF). Values significant different from those in control subjects are marked with *. IVS = interventricular septum, LVW = left ventricular free wall.

Ergebnisse für die mit dem Farbgewebedoppler ermittelten Myokardgeschwindigkeiten nach Belastung im Vergleich zwischen herzgesunden Probanden und Pferden mit Mitralklappeninsuffizienz (MVI), Aortenklappeninsuffizienz (AVI) oder Vorhofflimmern (VF). Werte die signifikant unterschiedlich zu den ermittelten Werten bei den gesunden Probanden waren sind mit * gekennzeichnet. IVS =Interventrikularseptum, LVW = Linksventrikuläre Hinterwand

\begin{tabular}{cccc}
\hline Parameter & Control $(\mathrm{n}=20)$ & MVI $(\mathrm{n}=15)$ & AVI $(\mathrm{n}=10)$ \\
\hline IVS_Systole $(\mathrm{cm} / \mathrm{s})$ & $-7.71 \pm 2.75$ & $-8.86 \pm 2.76$ & $-9.15 \pm 3.64$ \\
IVS_E-wave $(\mathrm{cm} / \mathrm{s})$ & $22.73 \pm 5.59$ & $21.93 \pm 9.25$ & $21.78 \pm 8.52$ \\
IVS_A-wave $(\mathrm{cm} / \mathrm{s})$ & $5.37 \pm 2.95(\mathrm{n}=12)$ & $7.39 \pm 8.16(\mathrm{n}=12)$ & $5.60 \pm 7.16(\mathrm{n}=7)$ \\
LVW_Systole $(\mathrm{cm} / \mathrm{s})$ & $10.64 \pm 2.79$ & $9.40 \pm 2.14$ & $9.80 \pm 2.90$ \\
LVW_E-wave $(\mathrm{cm} / \mathrm{s})$ & $-21.20 \pm 7.35$ & $-16.65 \pm 5.43$ & $-22.51 \pm 6.94$ \\
LVW_A-wave $(\mathrm{cm} / \mathrm{s})$ & $-8.62 \pm 3.7(\mathrm{n}=12)$ & $-10.54 \pm 7.74(\mathrm{n}=12)$ & $-11.86 \pm 2.05(\mathrm{n}=7){ }^{*} \mathrm{p}<0.05$ \\
\hline
\end{tabular}


possible to determine the a-wave are signed with $n$ (number of horses with a-wave) in table 4 and 5 .

Examination with colour-coded Tissue Doppler Imaging after exercise

As in rest, horses with atrial fibrillation demonstrated significant higher systolic myocardial velocities after exercise in the interventricular septum in comparison to the control subjects (Systole; control: $-7.71 \pm 2.75 \mathrm{~cm} / \mathrm{s}$, AF: $-10.84 \pm 3.20 \mathrm{~cm} / \mathrm{s}$, $p<0.001$ ) (table 4). Horses with aortic valve insufficiency demonstrated a higher end-diastolic myocardial velocity in the left ventricular free wall after exercise compared to the control subjects (control: $-8.62 \pm 3.7 \mathrm{~cm} / \mathrm{s}, \mathrm{AVI}:-11.86 \pm 2.05 \mathrm{~cm} / \mathrm{s}$, $\mathrm{p}<0.05$ ) (table 4). There were no significant changes in myocardial velocities in the horses with mitral valve insufficiency compared to the control objects after exercise.

\section{Examination with PW-Tissue Doppler after exercise}

The analysis of myocardial velocities with PW-Tissue Doppler after exercise demonstrated significant increased systolic velocities in the interventricular septum (control: $-13.37 \pm 3.84 \mathrm{~cm} / \mathrm{s}, \mathrm{AF}:-17.15 \pm 3.93 \mathrm{~cm} / \mathrm{s}, \mathrm{p}<0.005)$ as well in left ventricular free wall (control: $13.53 \pm 3.66 \mathrm{~cm} / \mathrm{s}$, AF: $17.95 \pm 3.50 \mathrm{~cm} / \mathrm{s}, \mathrm{p}<0.001$ ) in horses with atrial fibrillation compared to the control subjects (table 5). The horses with mitral- or aortic valve insufficiency did not show significant chances of myocardial velocity compared to the control subjects (Table 5).

\section{Discussion}

In the current study, it was possible to perform myocardial analysis with colour-coded Tissue Doppler and PW-Doppler at rest as well as after exercise. At rest, horses with mitral valve insufficiency or atrial fibrillation demonstrated an increase of myocardial systolic velocity compared to the control subjects. Furthermore, horses with atrial fibrillation also showed an increase of early diastolic myocardial velocity at rest, while in horses with aortic valve insufficiency only the early diastolic myocardial velocity was increased at rest compared to the control subjects.
This means, that the pathological regurgitation of the aortic valve at least when regarding the myocardial velocities did not influence the systole in the examined horses in the current study. In contrast, in horses with mitral valve insufficiency or atrial fibrillation, the increased volume overload and the therefore decreased stroke volume leads to an activation of baroreceptors in the aortic arch and carotid sinus. This is followed by a sympathicus activation and increase of contractility as a compensation mechanism (Mann 1999). This was observed in the horses with mitral valve insufficiency in the systole and in horses with atrial fibrillation also in the early diastolic phase. Overall, the increased filling pressure of the left ventricle leads to an activation of the Frank-Starling mechanisms with subsequent increased contractility and therefore increase of stroke volume (Wahi and Marwick 2007). In the presence of mitral or aortic valve insufficiency, depending on the severity of the insufficiency, a more or less increased volume overload of the left ventricle is present. Depending on the severity of the insufficiency and the change of ventricular architecture it comes to an activation of compensatory mechanisms, which first leads to an increase in myocardial velocities observed in humans as well as in dogs (Javornik 2007), maybe through a supranorrmal chamber elasticity (Carabello 1998). With increasing severity of the aortic as well as the mitral valve insufficiency, it comes to a decrease of myocardial velocities (Vinereanu et al. 20001, Haluska et al. 2003). The correlation of change in ventricular architecture and decrease in myocardial velocities has been reported in humans, where a decrease of $\beta$-receptors was associated with decreased diastolic velocities (Shan et a. 2000).

The majority of the examined horses in the present study only had mild to moderate insufficiencies of the mitral- or aortic valve. This explains why in mean an increase of the myocardial velocities was observed in the examined horses as a result of the only mild impaired cardiac function with subsequent compensatory increase of the stroke volume. Similar results have been observed in humans (Bruch et al. 2004) and in dogs (Javornik 2007). In dogs with mitral valve endocardiosis, mild to moderate valve insufficiency resulted in an increase of myocardial velocities, while only in cases of severe insufficiencies the myocardial velocities (systolic and diastolic) decreased (Javornik 2007). In contrast to the present study where radial myocardial velocities were examined, studies in humans and dogs mainly examine longitudinal myocardial velocities. However, the results of the studies can be

\footnotetext{
Table 5 Myocardial velocities after exercise measured with PW-Tissue Doppler Imaging in comparison between the control subjects and horses with mitral valve insufficiency (MVI), aortic valve insufficiency (AV), or atrial fibrillation (AF). Values significant different from those in control subjects are marked with *. IVS = interventricular septum, LVW = left ventricular free wall.

Ergebnisse für die mit dem PW-Gewebedoppler ermittelten Myokardgeschwindigkeiten nach Belastung im Vergleich zwischen herzgesunden Probanden und Pferden mit Mitralklappeninsuffizienz (MVI), Aortenklappeninsuffizienz (AVI) oder Vorhofflimmern (VF). Werte die signifikant unterschiedlich zu den ermittelten Werten bei den gesunden Probanden waren sind mit ${ }^{*}$ gekennzeichnet. IVS = Interventrikularseptum, $L V W=$ Linksventrikuläre Hinterwand.

\begin{tabular}{ccccc}
\hline Parameter & control $(\mathrm{n}=20)$ & MVI $(\mathrm{n}=15)$ & AVI $(\mathrm{n}=10)$ & VF $(\mathrm{n}=15)$ \\
\hline IVS_Systole $(\mathrm{cm} / \mathrm{s})$ & $-13.37 \pm 3.84$ & $-14.90 \pm 4.16$ & $-14.63 \pm 5.36$ & $-17.15 \pm 3.93^{*} \mathrm{p}<0.005$ \\
IVS_E-wave $(\mathrm{cm} / \mathrm{s})$ & $29.92 \pm 5.64$ & $30.96 \pm 11.73$ & $28.83 \pm 6.87$ & $29.93 \pm 11.37$ \\
IVS_A-wave $(\mathrm{cm} / \mathrm{s})$ & $9.41 \pm 4.08(\mathrm{n}=16)$ & $13.05 \pm 8.05(\mathrm{n}=14)$ & $9.48 \pm 6.74(\mathrm{n}=9)$ & $/$ \\
LVW_Systole $(\mathrm{cm} / \mathrm{s})$ & $13.53 \pm 3.66$ & $15.41 \pm 3.62$ & $12.73 \pm 3.03$ & $17.95 \pm 3.50^{*} \mathrm{p}<0.001$ \\
LVW_E-wave $(\mathrm{cm} / \mathrm{s})$ & $-32.17 \pm 6.44$ & $-30.44 \pm 6.13$ & $-30.60 \pm 6.49$ & $-32.12 \pm 9.13$ \\
LVW_A-wave $(\mathrm{cm} / \mathrm{s})$ & $-11.89 \pm 4.96(\mathrm{n}=16)$ & $-15.25 \pm 7.05(\mathrm{n}=12)$ & $-13.75 \pm 6.57(\mathrm{n}=8)$ & $/$ \\
\hline
\end{tabular}
}


compared because of the similar compensation mechanisms of electrophysiological or valvular changes in horses as in humans and dogs.

After exercise, the horses with atrial fibrillation also showed an increase of systolic myocardial velocities in the interventricular septum and left ventricular free wall as already observed at rest. This is probably due to the further increase of contractility (Frank-Starling mechanism) after exercise. This also explain the increase of the late diastolic myocardial velocity observed in the horses with aortic valve insufficiency as already observed in dogs with mitral valve endocardiosis (Javornik 2007). On the other side, the increase of late diastolic myocardial velocity in the horses with aortic valve insufficiency after exercise compared with the control subjects can be a sign of an impaired diastolic function as sign of an impaired diastolic relaxation as already reported in cats with Dystrophin-deficient hypertrophic muscular dystrophy at rest (Chetboul et al. 2006).

In human medicine, exercise tests with patients with chronic heart failure showed a correlation between exercise intolerance and decrease of systolic as well of late diastolic myocardial velocities (Witte et al. 2004). In contrast to those severely cardiac compromised affected human patients, the horses in the present studies were all - except 4 horses with atrial fibrillation - able to complete the exercise test without any harm. This means that the majority of the examined horses in the present study showed a milder affection of cardiac function than most of the human patients in exercise studies. A differential myocardial analysis of the interventricular septum and the left ventricular free wall during or after exercise in regard of different valvular insufficiencies has not been described in human or equine medicine (yet). This means that, in cases of more severe valvular diseases in horses, the myocardial kinetics observed in this study should not be used as an analogue to the human heart.

A limitation of the present study is first of all the angle dependency of the Tissue Doppler Imaging measurements. It was minimized by the alignment of the ventricle as parallel as possible to the ultrasound beam. Furthermore, the angle of $70^{\circ}$ resulted in a quite low frame rate of just above $60 \mathrm{fps}$. This may have led to an underestimation of the myocardial velocities. However, as all subjects were examined with the same settings, the importance of this low frame rate as a source of error can be neglected especially in the inter-individual comparison.

Although the importance of infarcts of the myocardium in horses is not nearly as high as in human medicine, the technique of myocardial analysis with Tissue Doppler Imaging can in future maybe detect signs of myocardial dysfunction in clinically not yet manifested infarct regions. Studies in human medicine demonstrated a decrease of systolic myocardial velocity in treadmill exercises in patients with coronary diseases (Pasquet et al. 1999).

Future studies have to show if the detected myocardial changes in the present study in horses without obvious limitations of exercise capacity, but with mild changes of the classic echocardiographic parameters (dimensions, valvular insufficiencies), are signs of an impaired cardiac function in peak performance, which was not nearly reached in the present study. Another interesting possibility would be an objective assessment of the development of the cardiac kinetic. This could especially be interesting in forensic questions.

Overall, the method of Tissue Doppler Imaging was practicable at rest as well as after exercise. Because of the short time frame available after exercise and the increased movements of the heart at high heart rates, the method of colour-code Tissue Doppler Imaging with the possibility of a subsequent off-line analysis was superior to the PW-Tissue Doppler technic and possibly more favourable in standard clinical settings with advanced technical equipment.

\section{Literature}

Abe M., Oki T., Tabata T., Luchi A., Ito S. (1999) Difference in the diastolic left ventricular wall motion velocities between aortic and mitral regurgitation by pulsed Doppler imaging. J. Am. Soc. Echocardiogr. 12, 15-21

Agricola E., Galderisi M., Oppzzi M. (2004) Pulsed Doppler imaging detects early myocardial dysfunction in asymptomatic patients with severe mitral regurgitation. Heart 90, 406-410

Bruch C., Marin D., Kuntz, Marin D., Kuntz S., Schmermund A., Bartel. T. (1999) Analysis of mitral annulus excursion with tissue doppler echocardiography. Noninvasive assessment of left ventricular diastolic dysfunction. Z. Kardiol. 88, 353-362

Bruch C., Stypmann J., Gradaus R., Breithardt G., Wichter T. (2004). Usefulness of tissue Doppler imaging for estimation of filling pressures in patients with primary or secondary pure mitral regurgitation. Am. J. Cardiol. 93, 324-328

Carabello B. A. (1998) Mitral valve regurgitation. Curr. Probl. Cardiol. 23, 202-241

Cardim N., Oliviera A. G., Longo S., Ferreira T., Pereira A., Reis R. P., Correia J. M. (2003) Doppler tissue imaging: regional myocardial dysfunction in hypertrophic cardiomyopathie and in athlete $s$ heart. J. Am. Soc. Echocardiogr. 3, 223-232

Chetboul V., Carlos C., Blot S. Thibaud J. L., Escriou C., Tissier R., Retortillo J., Pouchelon J. L (2004). Tissue Doppler assessment of diastolic and systolic alterations of radial and longitudinal left ventricular motions in Golden Retrievers during the preclinical phase of cardiomyopathy associated with muscular dystrophy. Am. J. Vet. Res 65, 1335-1341

Chetboul V., Blot S., Sampedrano C. C., Thibaud J. L., Escriou C., Tissier R., Retortillo J., Pouchelon J. L. (2006), Tissue Doppler Imaging for Detection of Radial and Longitudinal Myocardial Dysfunction in a Family of Cats Affected by Dystrophin-Deficient Hypertrophic Muscular Dystrophy. Vet. Intern. Med. 20, 640-647

Dagianti A., Vitarelli A., Conde Y., Penco M., Fedele F., Dagianti A. (2000) Assesment of left ventricular function during exercise test with pulsed Doppler imaging. Am. J. Cardiol. 86, 30G-32G

Decloedt A., Verheyen T., De Clercq D., Sys S., Vercauteren G., Ducatelle R., Delahaut P., van Loon G. (2012) Acute and LongTerm Cardiomyopathy and Delayed Neurotoxicity after Accidental Lasalocid Poisoning in Horses. Vet. Int. Med. 26, 1005-1011

Decloedt A., Verheyen T., van der Vekens N., Sys S., De Clerca D., van Loon G. (2013) Long-term follow-up of atrial function after cardioversion of atrial fibrillation in horses. Vet J. 197, 583-588.

Edvardsen T., Urheum S., Skulsted H., Steine K., Ihlen H., Smiseth O. A (2002) Quantification of left ventricular systolic function by tissue Doppler echocardiography: Added value of measuring preand postejection velocities in ischemic myocardium. Circulation 105, 2071-2077

Flachskampf F. A. (2002) Praxis der Echokardiographie. 1 Auflage, Thieme Verlag, Stuttgart, New York

Fukuda K., Oki T., Tabata T., luchi A., Ito S. (1998) Regional left wall motion abnormalities in myocardial infarction and mitral annular descent velocities studied with pulsed tissue Doppler. J. Am. Soc. Echocard. 11, 841-848 
Gehlen H. (1997) Beurteilung von Herzklappeninsuffizienzen beim Pferd mit der Farbdopplerechokardiographie durch Vermessung der Vena contracta. Diss. Med. Vet. Hannover

Gehlen H., Iversen C., Stadler P. (2009) Tissue Doppler echocardiographic examinations at rest and after exercise in horses with atrial fibrillation. Pferdeheilkunde 25, 11-16

Gehlen H. (2010). Kardiologische Diagnostik beim Pferd in der Praxis. Prakt. Tierarzt 91, 668-675

Gehlen H., Neukirch S. (2013) Tissue Doppler Imaging and Twodimensional Speckle Tracking of Left Ventricular Function in Horses Affected with Recurrent Airway Obstruction before and after Clenbuterol Treatment. Equine Vet. Sci. 33, 1076-1081

Haluska B. A., Short L., Marwick T. H. (2003) Relationship of ventricular longitudinal function to contractile reserve in patients with mitral regurgitation. Am. Heart J. 146, 183-188

Jassal D. S., Han S. Y., Hans C., Sharma A., Fang T., Ahmadie R., Lytwyn M., Walker J. R., Bhalla R. S., Czarnecki A., Moussa T., Singal P. K. (2009) Utility of tissue Doppler and strain rate imaging in the early detection of trastuzumab and anthracycline mediated cardiomyopathy. J. Am. Soc. Echocardiogr. 22, 418-424

Javornik A. (2007) Tissue Velocity, Strain und Strain Rate bei Hunden mit Mitralklappenendokardiose. Diss. Med. Vet. München

Kriz N. G., Hodgson D. R., Rose R. J. (2000) Prevalence and clinical importance of heart murmurs in racehorses. J. Am. Vet. Med.Assoc. 216, 1441-1445

Mann D. L. (1999) Mechanisms and models in heart failure a combinatorial approach. Circulation 100, 999-1008

Martin Jr. B. B., Reef V. B., Parente E. J., Sage A. D. (2000) Causes of poor performance of horses during training, racing, or showing: 348 cases (1992-1996). J. Am. Vet. Med. Assoc. 216, 554-558

McCulloch M., Zoghbi W. A., Davis R., Thomas C., Dokainish H. (2006) Color tissue Doppler myocardial velocities consistently underestimate spectral tissue Doppler velocities: impact on calculation peak transmitral pulsed Doppler velocity/early diastolic tissue Doppler velocity (E/Ea). Am. Soc. Echocardiogr. 6, 744-748

Michutta J. I. (2012) Einflüsse von Geräteeinstellungen auf myokardiale Geschwindigkeitsprofile in der Gewebedopplerechokardiographie beim Pferd. mbv, Mensch-und-Buch-Verlag. 1 Auflage, 1-132

Mishiro Y., Oki T., Yamada T., Wakatsuki T., Ito S. (1999) Evaluation of left ventricular contraction abnormalities in patients with dilated cardiomyopathy with the use of pulsed Doppler imaging. Am. Soc. Echocardiogr. 12, 913-920

Nagel D., Gehlen H. (2012) Influence of romifidine on myocardial function in horses with and without heart disease, evaluated with m-mode echocardiography and PW-tissue Doppler imaging. Berl. Münch. Tierärztl. Wschr. 126, 436-443

Nikitin N. P., Witte K. K. A. (2004) Application of Tissue Doppler Imaging in cardiology. Cardiology 4, 170-184

Deutsche Übersetzung

\section{Einsatz der Gewebedoppleruntersuchung beim Pferd - Vergleich stressechokardio- graphischer Gewebedopplermessung bei gesunden und herzkranken Warmblutpferden}

\section{Einleitung}

Erkrankungen des Herz-Kreislauf-Apparates gelten nach Obstruktionen der Atemwege und vor Muskelerkrankungen als die zweit-häufigste Ursache für Leistungsschwäche beim Pferd (Martin et al. 2000). Während Herzgeräusche bei Vollblutpferden nicht zwangsläufig mit deren Leistungsfähigkeit assoziiert sind (Kriz et al. 2000, Young et al. 2008), ist deren
Pasquet A., Armstrong L., Beachler L., Laver M. S., Marwick T. H. (1999) Use of segmental tissue Doppler velocity to quantify exercise echocardiography. Am. Soc. Echocardiogr. 12, 901-912

Patteson M. W., Gibbs C., Wotton P. R., Cripps P. J. (1995) Echocardiographic measurements of cardiac dimensions and indices of cardiac function in normal adult Thoroughbred horses. Equine Vet. J. 27, 18-27

Pellerin D., Sharma R., Elliot P., Veyrat C. (2003) Tissue Doppler, strain, and strain rate echocardiography for the assessment of left and right systolic ventricular function. Heart 89, iii9-iii 17

Schefer K. D., Bitschnau C., Weishaupt M. A., Schwarzwald C. C. (2010) Quantitative Analysis of Stress Echocardiograms in Healthy Horses with 2-Dimensional (2D) Echocardiography, Anatomical M-Mode, Tissue Doppler Imaging, and 2D Speckle Tracking. J. Vet. Int. Med. 24, 918-931

Schwarzwald C. C., Schober K. E., Bonagura J. D. (2007), Echocardiographic Evidence of Left Atrial Mechanical Dysfunction after Conversion of Atrial Fibrillation to Sinus Rhythm in 5 Horses. J. Vet. Int. Med. 21, 820-827

Schwarzwald C. C., Schober K. E., Bonagura J. D. (2009) Methods and Reliability of Tissue Doppler Imaging for Assessment of Left Ventricular Radial Wall Motion in Horses. Vet. Int. Mrd. 23, 643-652

Sepulveda M. F., Perkins J. D., Bowen I. M., Marr C. M. (2005) Demonstration of regional differences in equine ventricular myocardial velocity in normal 2-year-old Thoroughbreds with Doppler tissue imaging. Equine Vet. J. 37, 222-226

Stadler P., Höch M., Radü I. (1988) Methodik der Schnittbildechokardiographie beim Pferd. Pferdeheilkunde 4, 161-174

Vinereanu D., lonescu A. A., Fraser A. G. (2001) Assesment of left ventricular long axis contraction can detect early myocardial dysfunction in patients with severe aortic regurgitation. Heart 85, 30-36

Verheyen T., Decloedt A., De Clerca D., van Loon G. (2012), Cardiac Changes in Horses with Atypical Myopathy Vet. Int. Med. 26, 1019-1026

Voigt J. U. (2002) Gewebedoppler. In Praxis der Echokardiographie, Flachskampf, Erste Auflage, Thieme Verlag, Stuttgart, New York

Wahi S., Marwick T. H. (2007) Myocardial imaging in valvular heart diesease. In Marwick T. H., Yu C. M, Sun J. P. Myocardial imaging: Tissue Doppler and Speckle Tracking, 1st Edtion. Malden, Oxford, Carlton, Blackwell Futura, 223-233

Witte K. K. A., Nikitin N. P., De Silva R., Cleland J. G. F., Clark A. L. (2004). Exercise capacity and cardiac function assessed by tissue Doppler imaging in chronic heart failure. Heart 90, 1144-1150

Young L. E., Rogers K., Wood J. L. N. (2008) Heart Murmurs and Valvular Regurgitation in Thoroughbred Racehorses: Epidemiology and Associations with Athletic Performance. Vet. Int. Med. 22, 418-426

Bedeutung ohne weiterführende Untersuchungen bei Warmblutpferden oft unklar. Mit der echokardiographischen Ruheuntersuchung sowie einer elektrokardiographischen Untersuchung in Ruhe sowie in Belastung und gegebenenfalls über 24 Stunden kann das Herz weiterführend untersucht werden (Gehlen 2010). Insbesondere die Belastungsuntersuchung ist vor allem bei Pferden mit gering- oder mittelgradigen Klappeninsuffizienzen bedeutsam, da sowohl das Ausmaß einer eventuellen Leistungsbeeinträchtigung als auch eine Funktionsbeeinträchtigung des Herzens erst nach einer Belastung ausreichend beurteilt werden kann. Die standardisierte echokardiographische Untersuchung des Herzens umfasst die Vermessung der Herzdimensionen sowie die dopplersonographische Untersuchung der Herzklappen (Patteson et al. 1995). Zudem spielt die Funktionsdiagnostik des Myokards eine wichtige Rolle. Dabei kann die Methode der 
Gewebedopplerechokardiographie zur objektiven Beurteilung herangezogen werden (Pellerin et al. 2003).

Die Gewebedopplerechokardiographie wird auch als "Tissue Velocity Imaging" (TVI) oder "Tissue Doppler Imaging" (TDI) bezeichnet. Dabei können sowohl Spektral- als auch Farbdopplermodalitäten angewendet werden (Voigt 2002). In der Humanmedizin wird die Gewebedopplerechokardiographie zur Diagnostik ischämischer Herzerkrankungen mit Beurteilung diastolischer Funktionsstörungen (Bruch et al. 1999, Edvardsen et al. 2002), zur Früherkennung der dilatativen Kardiomyopathie (Fukuda et al. 1998, Mishiro et al. 1999), sowie zur Unterscheidung zwischen hypertropher Kardiomyopathie und trainingsbedingter Hypertrophie (Cardim et al. 2003) eingesetzt. Beim Menschen mit Klappeninsuffizienzen sind bei der Gewebedoppleruntersuchung je nach Klappenbefund und Grad der diastolischen Dysfunktion veränderte EWellen aufgefallen (Abe et al. 1999, Agricola et al. 2004). Mit der Stressechokardiographie werden Zusammenhänge zwischen Leistungsschwäche und erniedrigten spätdiastolischen sowie systolischen Myokardgeschwindigkeiten des linken Ventrikels beim Menschen erkannt (Witte et al. 2004). Bei Infarktpatienten lagen im Vergleich zu gesunden Menschen erniedrigte systolische Myokardgeschwindigkeiten vor (Dagianti et al. 2000).

Für die Stressechokardiographie eignet sich allerdings eher die Farbgewebedopplertechnik, weil damit nach Aufzeichnung der Herzzyklen (cineloops) zu einem späteren Zeitpunkt im off-line-Modus verschiedene Myokardsegmente zeitgleich und nachträglich analysiert werden können (Nikitin und Witte 2004). Mit der Farbgewebedopplerechokardiographie können allerdings lediglich Durchschnittsgeschwindigkeiten, mit der PW-Gewebedoppler-Technik können dagegen Spitzengeschwindigkeiten erfasst werden (McCulloch et al. 2006).

Durch die Gewebedopplerechokardiographie können zirkumferentielle, longitudinale sowie radiale Myokardgeschwindigkeiten ermittelt werden. Während in der Humanmedizin in den meisten Fällen die Untersuchung aus apikaler Anschallposition erfolgt und daher longitudinale Myokardgeschwindigkeiten erfasst werden können, sind beim Pferd aufgrund der parasternalen Anschallposition des Ventrikels mit der herkömmlichen Gewebedopplertechnik nur radiale Myokardgeschwindigkeiten zu erfassen (Flachskampf 2002, Sepulveda et al. 2005). Beim Pferd ist bisher die Anwendbarkeit der Gewebedopplerechokardiographie (Sepulveda et al. 2005, Schwarzwald et al. 2009, Michutta 2012), bei Lungenerkrankungen (Gehlen und Neukirch 2013), bei Vorhofflimmern in Ruhe (Schwarzwald et al. 2007, Decloedt et al. 2013) und nach Belastung (Gehlen et al. 2009, Schefer et al. 2010) sowie bei Intoxikationen (Decloedt et al. 2012, Verheyen et al. 2012) und während Sedierung (Nagel und Gehlen 2012) untersucht worden.

Ziel der vorliegenden Arbeit war der Vergleich der Myokardgeschwindigkeiten des linken Ventrikels von herzgesunden Warmblutpferden mit Warmblutpferden mit Herzklappeninsuffizienzen bzw. mit Vorhofflimmern in Ruhe sowie nach Belastung. Weiterhin sollte untersucht werden, ob und in welchen Ausmaß Klappenerkrankungen des Pferdes zu einer Veränderung der Myokardgeschwindigkeiten wie beim Mensch führen. Wenn dabei tatsächlich die Myokardgeschwindigkeit beeinflusst wird, erscheint eine Früherkennung myokardialer Dysfunktion und weitergehende Beurteilung der Leistungsfähigkeit und der weiteren Entwicklung der Herzerkrankung wie bei Mensch (Jassal et al. 2009) und Hund (Chetboul et al. 2004) auch beim Pferd nicht ausgeschlossen.

\section{Material und Methode}

Probandengut

Im Rahmen der Arbeit wurden 60 Warmblutpferde untersucht. Dabei handelte es sich zum einen um Patienten der Klinik für Pferde der Tierärztlichen Hochschule Hannover, und zum anderen um klinikeigene Pferde. Von den untersuchten Pferden waren 20 Pferde ohne Erkrankung des Herz-Kreislaufapparates und 40 Pferde mit Erkrankungen unterschiedlichen Schweregrades der Herzklappen oder mit Vorhofflimmern.

\section{Untersuchungen}

Bei alle Probanden erfolgten die Erhebung des Vorberichtes, eine klinische Allgemeinuntersuchung sowie eine spezielle Untersuchung des Herz-Kreislaufapparates mit EKG in Ruhe und in Belastung und eine echokardiographische Untersuchung. Die echokardiographische Voruntersuchung erfolgte mit Darstellung und Vermessung des Herzens in den standardisierten Schallkopfpositionen nach Stadler et al. (1988) mit dem Ultraschallgerät Vivid 7 (GE). Im Rahmen einer dopplersonographischen Untersuchung der Herzklappen wurden Klappeninsuffizienzen mittels Berechnung der Vena contracta nach Gehlen (1997) graduiert.

Die Gewebedopplerechokardiographie wurde bei allen Probanden in Ruhe und nach Belastung durchgeführt. Dabei wurde der Analysebereich des Interventrikularseptums (IVS) und der linksventrikulären Hinterwand (LVW) in der rechten kaudalen kurzen Achse (RKDKA) direkt unterhalb der Klappenebene mit einer Eindringtiefe von $28 \mathrm{~cm}$ und dem Bildwinkel von $70^{\circ}$ bei einer Bildrate von mindestens 60 bps dargestellt. Mit dem PW-Gewebedoppler und mit dem Farbgewebedoppler wurde der Mittelwert der frühdiastolischen Relaxation (E-Welle), der spätdiastolischen Relaxation (A-Welle) sowie der systolischen Spitzengeschwindigkeit aus je 3 Messungen im off-line-Modus (EchoPAC) ermittelt.

Die stressechokardiographische Untersuchung erfolgte nach einer standardisierten Longenbelastung über 20 Minuten (fünf Minuten Schritt, zehn Minuten Arbeitstrab und 5 Minuten Arbeitsgalopp). Sank die Herzfrequenz während der stressechokardiographischen Untersuchung unter 100 Schlägen pro Minute, wurde das Pferd erneut für einige Minuten im Galopp belastet.

\section{Statistische Auswertung}

Statistisch wurden bei allen Pferden die Mittelwerte und die Standardabweichung aus drei Herzzyklen mit dem SAS-Statistik-Programm bestimmt. Es wurden nur Herzzyklen ohne Arrhythmie berücksichtigt. Bei den Pferden mit Vorhofflimmern erfolgte die Mittelwertbestimmung aus fünf Herzzyklen. Die Daten wurden auf Normalverteilung geprüft und normal- 
verteilte Daten mit einem gepaarten t-test analysiert, während nicht normalverteilte Daten mit dem Wilcoxon-Test untersucht wurden. Das Signifikanzniveau wurde mit $p<0,05$ angegeben. Es wurden jeweils die herzgesunden Probanden mit den herzkranken Probanden sowohl in Ruhe als auch nach Belastung verglichen.

\section{Ergebnisse}

Voruntersuchungen

Gesunde Probanden

Das Durchschnittsalter der 20 herzgesunden Warmblutpferde (15 Wallache und fünf Stuten) betrug $11 \pm 5$ Jahre (3-20 Jahre), das mittlere Gewicht $605 \pm 72 \mathrm{~kg}(435-705 \mathrm{~kg})$ und die mittlere Größe $168 \pm 5 \mathrm{~cm}(158-180 \mathrm{~cm})$ im Stockmaß.

Die klinische Untersuchung war bei allen gesunden Probanden ohne besonderen Befund. Bei der echokardiographischen Voruntersuchung waren die Herzdimensionen innerhalb der Norm. Mittels Farbdoppler wurden bei zwei Pferden klappenschlussassoziierte Rückflüsse an den Aortenklappen sowie bei einem Pferd Rückflüsse an der Trikuspidal- und an der Pulmonalklappe festgestellt.

\section{Herzkranke Probanden}

Bei den herzkranken Probanden handelte es sich um 15 Pferde mit Mitralklappeninsuffizienz, 10 Pferde mit Aortenklappeninsuffizienz sowie 15 Pferde mit Vorhofflimmern. Die Gruppeneinteilung erfolgte nach der echo- und elektrographischen Untersuchung. Dabei wurde bei den Pferden mit Aorten- bzw. Mitralklappeninsuffizienz nur Pferde in der Auswertung mit eingeschlossen, die nur an einer Herzklappe (Mitral- oder Aortenklappen) relevante Rückflüsse aufwiesen.

\section{Mitralklappeninsuffizienz}

In der Gruppe der Pferde mit Mitralklappeninsuffizienz (15 Pferde) betrug das Durchschnittsalter $9 \pm 5$ Jahre (4-21 Jahre), das mittlere Gewicht $572 \pm 44 \mathrm{~kg}(515-660 \mathrm{~kg})$ und die mittlere Größe $168 \pm 5 \mathrm{~cm}(155-173 \mathrm{~cm})$ im Stockmaß. Nach Einteilung der Schweregrad mittels Bestimmung der Vena contracta hatten 12 Pferde eine geringgradige, 2 eine mittelgradige und 1 Pferd eine hochgradige Mitralklappeninsuffizienz.

\section{Aortenklappeninsuffizienz}

In der Gruppe der Pferde mit Aortenklappeninsuffizienz (10 Pferde) betrug das Durchschnittsalter 13 44 Jahre (5-18 Jahre), das mittlere Gewicht $516 \pm 54 \mathrm{~kg}(442-600 \mathrm{~kg})$ und die mittlere Größe $161 \pm 5 \mathrm{~cm}(150-169 \mathrm{~cm})$ im Stockmaß. Nach Einteilung der Schweregrad mittels Bestimmung der Vena contracta hatten 5 Pferde eine geringgradige, 3 eine mittelgradige und 2 Pferde eine hochgradige Aortenklappeninsuffizienz.

\section{Vorhofflimmern}

In der Gruppe der Pferde mit Vorhofflimmern (15 Pferde) betrug das Durchschnittsalter $10 \pm 5$ Jahre (3-18 Jahre), das mittlere Gewicht $597 \pm 74 \mathrm{~kg}(480-705 \mathrm{~kg})$ und die mittlere Größe $173 \pm 9 \mathrm{~cm}(160-186 \mathrm{~cm})$ im Stockmaß.

\section{Gewebedoppleruntersuchungen in Ruhe}

Bei den Pferden mit Vorhofflimmern konnte aufgrund der fehlenden Vorhofkontraktion keine Bestimmung der A-Welle durchgeführt werden.

\section{Untersuchungen mittels Farbgewebedoppler in Ruhe}

Im Rahmen der Farbgewebedoppleruntersuchung in Ruhe (Tabelle 1) zeigte sich im Vergleich zwischen herzgesunden herzkranken Probanden signifikante Unterschiede bei den Pferden mit Vorhofflimmern, welche eine höhere systolische und frühdiastolische Myokardgeschwindigkeit sowohl im Interventrikularseptum (Systole; gesund : - 3,92 $\pm 1,54 \mathrm{~cm} / \mathrm{s}$, VF: $-6,66 \pm 3,26 \mathrm{~cm} / \mathrm{s}, \quad p<0,0001$, E-Welle; gesund: $12,34 \pm 2,91 \mathrm{~cm} / \mathrm{s}, V F: 16,70 \pm 6,13 \mathrm{~cm} / \mathrm{s}, \mathrm{p}<0,001)$ als auch in der Hinterwand (Systole; gesund: 7,14 $1,18 \mathrm{~cm} / \mathrm{s}$, VF: $10,03 \pm 3,10 \mathrm{~cm} / \mathrm{s}, \quad \mathrm{p}<0,0001$, E-Welle; gesund: $-17,32 \pm 5,25 \mathrm{~cm} / \mathrm{s}, V F:-22,25 \pm 5,19 \mathrm{~cm} / \mathrm{s}, \mathrm{p}<0,01)$ aufwiesen. Der Vergleich zwischen herzgesunden Pferden und den Probanden mit Klappeninsuffizienzen erbrachte keine signifikanten Unterschiede.

Untersuchungen mittels PW-Gewebedoppler in Ruhe

Bei den mittels PW-Gewebedoppler ermittelten Myokardgeschwindigkeiten in Ruhe zeigten die Pferde mit Vorhofflimmern signifikant höhere systolische und frühdiastolische Myokardgeschwindigkeiten als die herzgesunden Probanden, sowohl im Bereich des Interventrikulärseptum (Systole; gesund: $\quad-8,36 \pm 1,78 \mathrm{~cm} / \mathrm{s}, \quad V F:-12,16 \pm 3,56 \mathrm{~cm} / \mathrm{s}$, $\mathrm{p}<0,0001$, E-Welle; gesund: $17,06 \pm 3,85 \mathrm{~cm} / \mathrm{s}$, VF: $22,44 \pm 8,08 \mathrm{~cm} / \mathrm{s}, \mathrm{p}<0,005)$ wie auch im Bereich der linksventrikulären Hinterwand (Systole; gesund: $11,15 \pm 3,05 \mathrm{~cm} / \mathrm{s}, V F: 15,48 \pm 4,78 \mathrm{~cm} / \mathrm{s}, \mathrm{p}<0,0005, \mathrm{E}-$ Welle; gesund: $-25,97 \pm 6,21 \mathrm{~cm} / \mathrm{s}, \mathrm{VF}:-31,81 \pm 7,84 \mathrm{~cm} / \mathrm{s}$, $\mathrm{p}<0,01$ ) (Tabelle 2). Des Weiteren lag bei den Pferden mit Aortenklappeninsuffizienz eine höhere frühdiastolische Myokardgeschwindigkeit im Bereich des Interventrikulärseptums vor als bei den herzgesunden Pferden (gesund: $17,06 \pm 3,85 \mathrm{~cm} / \mathrm{s}, \quad \mathrm{AVI}: 20,30 \pm 3,59 \mathrm{~cm} / \mathrm{s}, \quad \mathrm{p}<0,05)$ (Tabelle 2). Bei den Pferden mit Mitralklappeninsuffizienz lag eine Erhöhung der systolischen Myokardgeschwindigkeit im Bereich des interventrikulären Septums im Vergleich zu den herzgesunden Probanden vor (gesund: - 8,36 $\pm 1,78 \mathrm{~cm} / \mathrm{s}$, MVI: $-10,99 \pm 3,13 \mathrm{~cm} / \mathrm{s}, \mathrm{p}<0,005)$.

\section{Belastungsuntersuchung}

Sowohl bei den gesunden Probanden als auch bei den Pferden mit Mitralklappen- oder Aortenklappeninsuffizienz war eine vollständige Longenbelastung über 20 Minuten möglich, während 4 Probanden mit Vorhofflimmern aufgrund vorzeitiger Erschöpfung nicht über den gesamten Zeitraum belastet werden konnten. Die ermittelten Herzfrequenzen nach Belastung sowie die Durchschnittsgeschwindigkeit im Trab und Galopp sind in Tabelle 3 aufgeführt.

\section{Gewebedoppleruntersuchungen nach Belastung}

Bei der Gewebedoppleruntersuchung nach Belastung lag bei einem Teil der untersuchten Pferde eine Verschmelzung der AWelle mit der E-Welle vor, so dass diese (A-Welle) nicht aus- 
gewertet werden konnte. Der Anzahl der auswertbaren Pferde sind in den Tabellen 4 und 5 aufgeführt.

Untersuchungen mittels Farbgewebedoppler nach Belastung

Auch nach Belastung lag bei den Probanden mit Vorhofflimmern eine signifikant höhere systolische Myokardgeschwindigkeit im Bereich des Interventrikularseptums (Systole; gesund: - 7,71 $\pm 2,75 \mathrm{~cm} / \mathrm{s}, V F:-10,84 \pm 3,20 \mathrm{~cm} / \mathrm{s}, \mathrm{p}<0,001$ ) (Tabelle 4) vor als bei den gesunden Kontrollpferden. Die Pferde mit Aortenklappeninsuffizienz zeigten eine signifikante Erhöhung der spätdiastolischen Myokardgeschwindigkeit im Bereich der linksventrikulären Hinterwand im Vergleich zu den herzgesunden Pferden (gesund: $-8,62 \pm 3,7 \mathrm{~cm} / \mathrm{s}$, AVI: $-11,86 \pm 2,05 \mathrm{~cm} / \mathrm{s}, \mathrm{p}<0,05)$ (Tabelle 4).

\section{Untersuchungen mittels PW-Gewebedoppler nach Belastung}

Bei den mittels PW-Gewebedoppler ermittelten Myokardgeschwindigkeiten lag bei den Pferden mit Vorhofflimmern sowohl im Bereich des interventrikulären Septum (gesund: - 13,37 $\pm 3,84 \mathrm{~cm} / \mathrm{s}$, VF: $-17,15 \pm 3,93 \mathrm{~cm} / \mathrm{s}, \mathrm{p}<0,005)$ als auch im Bereich der linksventrikulären Hinterwand (gesund: $13,53 \pm 3,66 \mathrm{~cm} / \mathrm{s}$, VF: $17,95 \pm 3,50 \mathrm{~cm} / \mathrm{s}, \mathrm{p}<0,001)$ eine signifikante Erhöhung des systolischen Myokardgeschwindigkeiten vor (Tabelle 5). Bei den Probanden mit Klappeninsuffizienzen zeigten sich keine signifikanten Unterschied zu den herzgesunden Probanden (Tabelle 5).

\section{Diskussion}

Im Rahmen der vorliegenden Studie konnten Myokardanalysen mittels PW-Gewebedoppler und Farbgewebedoppler sowohl in Ruhe als auch in Belastung durchgeführt werden.

In Ruhe zeigten Patienten mit Mitralklappeninsuffizienz oder Vorhofflimmern eine erhöhte systolische Myokardgeschwindigkeit. Pferde mit Vorhofflimmern zeigten im Vergleich zu den herzgesunden Pferden zusätzlich zu der systolisch erhöhten Myokardgeschwindigkeit eine Erhöhung der frühdiastolischen Myokardgeschwindigkeit in Ruhe, während bei den Pferden mit Aortenklappeninsuffizienz im Vergleich zu den herzgesunden Probanden ausschließlich eine höhere frühdiastolische Myokardgeschwindigkeit in Ruhe vorlag. Das bedeutet, dass sich an der Aortenklappe in Ruhe der pathologische Rückfluss zumindest in Bezug auf die Myokardgeschwindigkeit, nicht bis in die Systole bei den untersuchten Pferden auswirkt. Dagegen entsteht bei Mitralklappeninsuffizienz bzw. bei Vorhofflimmern durch die Volumenbelastung des linken Vorhofes ein Abfall des Auswurfsvolumens. Dies wird zunächst durch Aktivierung von Barorezeptoren im Aortenbogen und Karotissinus mit Sympathikusaktivierung und nachfolgender Erhöhung der Kontraktilität kompensiert (Mann 1999) wie bei den Pferden mit MVI des hier untersuchten Patientengutes in Ruhe ausschließlich systolisch und beim Vorhofflimmern zusätzlich auch frühdiastolisch. Das bedeutet, dass bei den Pferden mit Mitralklappeninsuffizienz es zu einer Erhöhung der systolischen Myokardgeschwindigkeit kommt, während bei den Pferden mit Vorhofflimmern sowohl die systolischen wie auch die frühdiastolischen Myokardgeschwindigkeiten im Vergleich zu den gesunden Probanden zunimmt. Insgesamt führt der erhöhte Füllungsdruck des linken Ventrikels durch den Frank-Starling-Mechanismus synchron zur Erhöhung des Schlagvolumens (Wahi und Marwick 2007).
Im Rahmen der Aortenklappeninsuffizienz als auch bei der Mitralklappeninsuffizienz entsteht je nach Ausprägung eine mehr oder weniger deutlich vermehrte Volumenbelastung des linken Ventrikels. Je nach Schweregrad der Klappeninsuffizienz und damit verbundene Veränderung der Ventrikelarchitektur kommt es zunächst durch Aktivierung kompensatorischer Mechanismen zur Erhöhung der Myokardgeschwindigkeiten sowohl beim Mensch wie auch beim Hund (Javornik 2007) eventuell durch eine supranormale Kammerelastizität (Carabello 1998) während bei zunehmendem Schweregrad der Aortenklappen- als auch der Mitralklappeninsuffizienz die Geschwindigkeit der Myokardbewegung jedoch wieder abnimmt (Vinereanu et al. 2001, Haluska et al. 2003).

Der Zusammenhang zwischen Formveränderung und Myokardgeschwindigkeiten sind bei Menschen nachgewiesen worden, wo eine Abnahme der Dichte der -Rezeptoren des Myokards mit erniedrigten diastolischen Myokardgeschwindigkeiten zusammenhingen (Shan et al. 2000).

In der vorliegenden Studie sind vornehmlich geringgradig erkrankte Pferde untersucht worden. Daher führt bei allen hier untersuchten Störungen der Herzfunktion -der geringgradig vermehrte Füllungsdruck und das damit einhergehende kompensatorisch erhöhte Schlagvolumen im Mittel zur Erhöhung der systolischen Geschwindigkeit des Ventrikelmyokards mit Aufrechterhaltung der Ventrikelfunktion. Ähnliche Ergebnisse sind bei Menschen (Bruch et al. 2004) und bei Hunden (Javornik 2007) berichtet worden. Bei Hunden mit gering- bis mittelgradigen Mitralklappenendokardiosen kam es zunächs† zu einer Zunahme und erst bei hochgradig erkrankten Hunden zu einem Abfall der Myokardgeschwindigkeit (sowohl systolisch wie auch diastolisch) (Javornik 2007). Im Gegensatz zur vorliegenden Studie sind bei Mensch und Hund nicht radiale, sondern longitudinale Myokardgeschwindigkeiten gemessen worden. Dennoch lassen sich die Ergebnisse vergleichen, da dem Pferdeherzen weitgehend der gleiche Mechanismus zur Kompensation elektrophysiologischer oder klappenmechanischer Veränderungen zugrunde liegt wie dem Menschen und dem Hund.

Nach der Belastung zeigten die Pferde mit Vorhofflimmern wie bereits auch in Ruhe (s. oben) eine erhöhte systolische Myokardgeschwindigkeit sowohl im Bereich des Septums wie auch im Bereich der Hinterwand. Dies ist wahrscheinlich durch die in Belastung deutlicher erhöhte Kontraktilität (Frank-Starling-Mechanismus) bedingt. Damit ist auch die Erhöhung der spätdiastolischen Myokardgeschwindigkeit bei den Pferden mit Aortenklappeninsuffizienz, wie auch bei den Hunden mit Mitralklappenendokardiose erklärbar (Javornik 2007). Andererseits kann die spätdiastolische Myokardgeschwindigkeit bei AVI nach Belastung auch ein Zeichen einer diastolischen Funktionsstörung im Sinne einer Störung der myokardialen Relaxation sein, wie bei Katzen mit Dystrophindeficient hypertrophic muscular dystrophy bereits in Ruhe festgestellt, sein (Chetboul et al. 2006).

In der Humanmedizin konnte im Rahmen von Belastungsuntersuchungen bei Patienten mit chronischem Herzversagen ein Zusammenhang zwischen Leistungsinsuffizienz und Abnahme der systolischen sowie spätdiastolischen Myokardgeschwindigkeiten festgestellt werden (Witte et al. 2004). Im Gegensatz zu derart schwer erkrankten Herzen des Men- 
schen, wurden in der vorliegenden Studie Pferde untersucht, die, bis auf 4 Pferde mit Vorhofflimmern, alle die Belastungsuntersuchung, ohne Schaden zu nehmen, ausführen konnten. D.h es handelt sich um Patienten mit einem deutlich geringerem Erkrankungsgrad als in den meisten humanmedizinischen Studien dieser Art. Eine differenzierte Betrachtung des Hinterwandmyokards einerseits und des Septummyokards andererseits liegt für die Bewegungsanalyse des menschlichen Herzens und insbesondere des Pferdeherzens bei unterschiedlichen Klappeninsuffizienzen bis jetzt (noch) nicht vor, so dass für höhergradige Klappenerkrankungen des Pferdes nicht auf der Basis der myokardialen Kinetik des Pferdeherzens der Patienten dieser Studie auf eine Analogie mit dem menschlichen Herzen geschlossen werden sollte.

Limitationen der vorliegenden Studie sind vor allem die Winkelabhängigkeit der Gewebedopplermessungen, wie bei jeder Dopplermessung. Dies wurde durch ein annähernd paralleles Ausrichten des linken Ventrikels zu dem Schallstrahl so weit wie möglich reduziert. Weiterhin wurden in der Studie durch die Weite des Bildwinkels relativ niedrige Bildraten (knapp über $60 \mathrm{bps}$ ) erreicht. Dies kann durchaus zu einer Unterschätzung der tatsächlichen Myokardgeschwindigkeiten geführt haben. Da allerdings die untersuchten Pferde alle mit derselben Einstellung und Bildrate untersucht wurden, wird der Einfluss dieser Fehlerquelle, insbesondere im interindividuellen Vergleich, nicht als bedeutsam eingeschätzt. Obwohl Infarkten des Herzmuskels beim Pferd nicht die gleiche
Bedeutung zukommt wie beim Menschen, könnte diese Untersuchungstechnik in der Zukunft Hinweise für eine myokardiale Dysfunktion in zunächst klinisch noch nicht manifesten Infarktbereichen im Sinne einer Früherkennung liefern. Humanmedizinische Studien zeigten nämlich eine Abnahme der systolischen Myokardgeschwindigkeiten in Infarktbereichen im Rahmen von Laufbandbelastungen bei Patienten mit koronaren Herzerkrankungen (Pasquet et al. 1999).

Zukünftige Untersuchungen müssen zeigen, ob bereits die hier erfassten Veränderungen der Myokardgeschwindigkeiten bei Pferden ohne deutliche Einschränkung der Leistungsfähigkeit, jedoch mit geringgradigen Veränderungen der klassischen echokardiographischen Parameter (z.B. ggr. Dimensionsveränderungen, Rückflüsse) Hinweise für Einschränkungen der Herzfunktion bei Spitzenleistungen, die in der vorliegenden Studie nicht annähernd erbracht wurden oder für Entwicklungen der Herzkinetik in der Zukunft geben können. Das könnte nicht zuletz† forensisch bedeutsam sein. Insgesamt zeigte sich die Methode der Gewebedopplertechnik auch beim Pferd sowohl in Ruhe wie auch nach Belastung anwendbar. Aufgrund der kurzen Zeitspanne der Untersuchungsmöglichkeit nach Belastung und aufgrund der ausgeprägten Bewegung des Herzens bei hohen Herzfrequenzen zeigte sich allerdings die Methode der Farbgewebedopplerechokardiographie, wie sie in der vorliegende Studie zur Anwendung kam, für eine kardiologische Routinediagnostik mit hochwertiger technischer Ausrüstung vorteilhaft. 